\title{
Decision Support System Recipient In the House Surgery Department of Housing and Settlement Region Deli Serdang Using TOPSIS Method
}

\author{
Irwanda Prayogi ${ }^{1}$, Bosker Sinaga ${ }^{2}$ \\ ${ }^{1,2}$ Informatics Engineering Study Program, STMIK Pelita Nusantara, Jl. St. Iskandar Muda No. 1 Medan, \\ Nort Sumatera, Indonesia 20154 \\ E-mail:irwanda_prayogi@yahoo.co.id ${ }^{1}$,sinagab8@gmail.com²
}

\begin{abstract}
The Inappropriate Home Assistance Program (PRTLH) or Home Renovation is assistance provided by the government to people who are Unable to reduce the economic burden. This assistance can be Obtained if the prospective beneficiary meets the specified criteria and conditions. This research is motivated by the house renovation assistance to the community is still subjective, less objective in the selection of the data and the weakness of the system used today. Therefore to help in the selection, a system for decision support was made in Determining the prospective recipient of house surgery assistance using the web-based TOPSIS method using a MySQL database, so that it can help smooth the evaluation process in the selection of subsequent home surgery recipients.
\end{abstract}

Keywords: Inappropriate Home Assistance Program, Decision Support System, TOPSIS, Web, MySQL

\section{Introduction}

The development of technology and science very much to bring change in every aspect of human life, including in the areas of government, especially the problem of improving the welfare of society [2]. In general SPK, used as a decision support system, not to replace them [1]. Including, in decision making surgical recipients at the Department of Housing and Settlement Region Deli Serdang. Department of Housing and Area Settlement Deli Serdang is an agency established by the Government of Deli Serdang have a vision of the establishment of adequate housing productive, environmentally sustainable, including through assistance programs surgical or PRTLH (Program Home Not Livable) which is regularly held every year. Home or surgical assistance program should be given to the recipient PRTLH feasible and worth untukmendapatkannya [5]. The number of people eligible to receive assistance made the house surgeon Department of Housing and Settlement Region Deli Serdang have to be very selective to provide surgical assistance. Problems often arise which houses the surgical aid distribution to the public are subjective, not objective in the selection of data, lack of a system to make decisions. Department of Housing and Settlement Region Deli Serdang beneficiary selection process requires that routine surgical and quickly so as to provide feedback and rapid improvement in the Department of Housing and Settlement Region Deli Serdang.

\section{Theory}

\subsection{Decision Support System}

Decision Support System is a system used to support in making managerial decisions in certain cases [4].

2.2 Decision Support System Components

Decision support systems are divided into three main components, namely [3]:

a) Data Subsystem (Database)

Data Subsystem is a system component in making a decision that serves as a data provider for the system.

b) Model Subsystem (Base Model)

The model is suatusistem imitation of the real world. Problems encountered in the design of the model is a model not able to describe the real world variables.

c) Dialog Subsystem (User System Interface)

Yaitusuatufasilitas dialog subsystem to integrate the systems which are used by interactive users, known as the subsystems dialogue. 


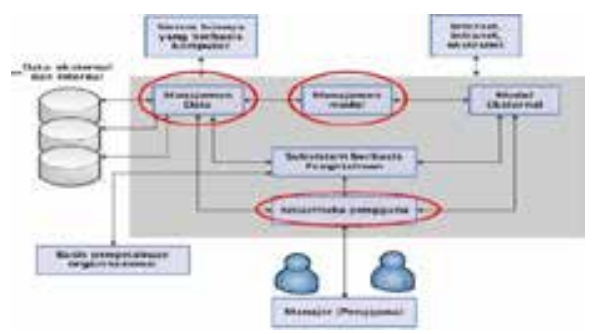

Fig 1. SPK components

a. TOPSIS (Technique For Order Preference by Similarity to Ideal Solution)

TOPSIS method is used as a method to solve the problem of multi-criteria. The following stages of the method TOPSIS [6]:

1) TOPSIS starts with making a decision matrix.

$$
X=\begin{array}{cccc}
a_{1} & x_{11} & \cdots & x_{1 n} \\
\vdots & \vdots & \ddots & \vdots \\
a_{m} & x_{m 1} & \cdots & x_{m n}
\end{array}
$$

where ai $(\mathrm{i}=1,2,3, \ldots, \mathrm{m})$ is a possible alternative, $x j(\mathrm{~J}=1,2,3, \ldots, \mathrm{n})$

2) Make a normalized decision matrix.

$$
r_{i j}=\frac{x_{i j}}{\sqrt{\sum_{i=1}^{m} x_{i j}{ }^{2}}}
$$

with $\mathrm{i}=1,2,3, .,,, \mathrm{M}$; and $\mathrm{j}=1,2,3, .,,, \mathrm{N}$

3) Make a normalized weighted decision matrix

with a weight $w i=w 1, w 2, w 3, \ldots, w n$ Where $w j$ is weights of criterion $\mathrm{j}$

$$
{ }_{j=1}^{n} w_{j}=1
$$

the normalization of weight matrix $\mathrm{V}$ is:

$$
v_{i j}=w_{j} r_{i j}
$$

with $\mathrm{i}=1,2,3, .,,, \mathrm{M}$; and $\mathrm{j}=1,2,3, .,,, \mathrm{N}$;

Where vijis the weighted normalized decision matrix elements $\mathrm{V}$.

4) Determining the ideal solution matrix positive and idealnegatif solutions.

a.

$$
\begin{aligned}
& A^{+}=\left\{\left(\max v_{i} \mid j \in J\right),\left(\min v_{i j} \mid j \in J^{+}\right), i=1,2,3, \ldots, m \ldots\right. \\
& \left.=t v^{*}, v^{*}, v^{*}, \ldots, v^{*}\right\} \\
& \text { b. } \left.A^{-}=\left(\min v_{i j} \mid j \in J\right),\left(\max v_{i} \mid j \in J^{\prime}\right), i=1,2,3, \ldots, m\right\} \\
& =\left\{\begin{array}{c}
\left.v^{-}, v^{-}, v^{-}, \ldots, v^{-}\right\} \\
1
\end{array}\right.
\end{aligned}
$$

Where vijis the weighted normalized decision matrix elements $\mathrm{V}$.

5) Calculate Seperation.

a) $S+$ is an alternative distance of the positive ideal solution, namely:

$$
S_{i}^{+}=\overline{n_{j=1}^{n} V_{i j}-V_{j}^{+2}} \text {, With } \mathrm{i}=1,2,3, \ldots, \mathrm{m}
$$

b) $S$-is an alternative distance from the negative ideal solution is:

$$
S_{i}^{-}=\overline{n_{j=1}^{n} V_{i j}-V_{j}^{-2}} \text {, with } \mathrm{i}=1,2,3, \ldots, \mathrm{m}
$$


6) Calculating the relative closeness of the solution idealpositif.

$$
c_{j}^{+}=\frac{s_{i}^{-}}{S_{i}^{-}+S_{i}^{+}}, 0 \leq C_{i}^{+} \leq 1
$$

d) Results and Discussion 2020:

Here beneficiary data surgical Settlement Region Department of Housing and Deli Serdang Year Period

Table 1.

Data Recipient House Surgery

\begin{tabular}{|c|c|c|c|c|c|c|c|}
\hline No. & Name & $\begin{array}{l}\text { Building } \\
\text { area }\end{array}$ & $\begin{array}{c}\text { Wall } \\
\text { conditions }\end{array}$ & $\begin{array}{c}\text { Condition } \\
\text { Roof }\end{array}$ & $\begin{array}{l}\text { Floor } \\
\text { condition }\end{array}$ & Income & Land ownership \\
\hline 1. & Mawan & $<=30 \mathrm{~m}^{2}$ & Board & Well & Plaster & 1.2 Million & Right of ownership \\
\hline 2. & Mursiah & $<=30 \mathrm{~m}^{2}$ & Board & Well & Plaster & 1.2 Million & Right of ownership \\
\hline 3. & Asri & $>30 \mathrm{~m}^{2}$ & Board & Damaged lightly & Plaster & 1.2 Million & Right of ownership \\
\hline 4. & Misiah & $>30 \mathrm{~m}^{2}$ & Board & Damaged lightly & Plaster & 1.2 Million & Right of ownership \\
\hline 5. & Wagiman & $>30 \mathrm{~m}^{2}$ & Board & Damaged lightly & Plaster & 1.2 Million & Right of ownership \\
\hline
\end{tabular}

Table 2.

Values Criteria

\begin{tabular}{llcccccc}
\hline No. & Name & $\begin{array}{c}\text { Building } \\
\text { area }\end{array}$ & $\begin{array}{c}\text { Wall } \\
\text { conditions }\end{array}$ & $\begin{array}{c}\text { roof } \\
\text { condition }\end{array}$ & $\begin{array}{c}\text { Floor } \\
\text { condition }\end{array}$ & Income & $\begin{array}{c}\text { Land } \\
\text { ownership }\end{array}$ \\
\hline 1. & Mawan & 5 & 4 & 1 & 3 & 4 & 5 \\
2. & Mursiah & 6 & 5 & 1 & 3 & 6 & 5 \\
3. & Asri & 2 & 4 & 3 & 4 & 5 & 6 \\
4. & Misiah & 2 & 4 & 3 & 3 & 5 & 4 \\
5. & Wagiman & 1 & 5 & 4 & 3 & 4 & 5 \\
\hline
\end{tabular}

\subsection{TOPSIS Algorithm Analysis}

TOPSIS algorithm in the decision support system beneficiaries house surgeon at the Department of Housing and Settlement Region using TOPSIS method are:

a) Enter data of beneficiaries surgical criteria and weighting of each criterion that has been converted kenilai fuzzy.

Ai = Mawan, Mursiah, Asri, Misiah, Wagiman

$\mathrm{Cj}=$ Building, Wall Condition, Condition Roofs, Floor Condition, Income, Land Tenure

b) Weights determine references to criteria $(\mathrm{C} 1, \mathrm{C} 2, \mathrm{C} 3, \mathrm{C} 4, \mathrm{C} 5$ and $\mathrm{C} 6)$ is $(0.2 ; 0.2 ; 0.2 ; 0.1 ; 0.2 ; 0.1)$

c) Build Matrix decision normalized from each category is represented by X (i) dimana $\mathrm{i}=1,2,3,4,5$ and 6 . The normalization formula is matrix as follows:

$$
r_{i j}=\frac{x_{i j}}{{\underset{i=1}{m} x_{i j^{2}}}^{m}}
$$

with $\mathrm{i}=1,2, \ldots, \mathrm{m}$ and $\mathrm{j}=1,2, \ldots, \mathrm{n}$

then:

Based on the above calculation, the matrix obtained normalized decision namely:

Table 3.

Normalization Matrix Data

\begin{tabular}{clcccccc}
\hline No. & Name & $\mathrm{R}(\mathrm{i}, 1)$ & $\mathrm{R}(\mathrm{i}, 2)$ & $\mathrm{R}(\mathrm{i}, 3)$ & $\mathrm{R}(\mathrm{i}, 4)$ & $\mathrm{R}(\mathrm{i}, 5)$ & $\mathrm{R}(\mathrm{i}, 6)$ \\
\hline 1. & Mawan & 0.707107 & 0.447214 & 0 & 0.447214 & 0.447214 & 0.447214 \\
2. & Mursiah & 0.707107 & 0.447214 & 0 & 0.447214 & 0.447214 & 0.447214 \\
3. & Asri & 0 & 0.447214 & 0.577350 & 0.447214 & 0.447214 & 0.447214 \\
4. & Misiah & 0 & 0.447214 & 0.577350 & 0.447214 & 0.447214 & 0.447214 \\
5. & Wagiman & 0 & 0.447214 & 0.577350 & 0.447214 & 0.447214 & 0.447214 \\
\hline
\end{tabular}

d) Make a decision that the normalized weighted matrix (V) whose elements are determined from R (i). Weighted normalized decision matrix calculation is as follows:

$$
V_{i j}=W_{j} r_{i j} V_{i j}
$$

Dengani $=1,2,3, \ldots, \mathrm{m} ;$ and $\mathrm{j}=1,2,3, \ldots, \mathrm{n}$; 
and the weighting of each criterion reference. $W_{j}$

From the calculations, the weighted normalized decision matrix such as the following table:

Table 4.

Weighted normalized Decision Matrix

\begin{tabular}{ccccccc}
$\mathrm{i}$ & $\mathrm{V}(\mathrm{i}, 1)$ & $\mathrm{V}(\mathrm{i}, 2)$ & $\mathrm{V}(\mathrm{i}, 3)$ & $\mathrm{V}(\mathrm{i}, 4)$ & $\mathrm{V}(\mathrm{i}, 5)$ & $\mathrm{V}(\mathrm{i}, 6)$ \\
\hline 1 & 0.1414214 & 0.0894428 & 0 & 0.0447214 & 0.0894428 & 0.0447214 \\
2 & 0.1414214 & 0.0894428 & 0 & 0.0447214 & 0.0894428 & 0.0447214 \\
3 & 0 & 0.0894428 & 0.11547 & 0.0447214 & 0.0894428 & 0.0447214 \\
4 & 0 & 0.0894428 & 0.11547 & 0.0447214 & 0.0894428 & 0.0447214 \\
5 & 0 & 0.0894428 & 0.11547 & 0.0447214 & 0.0894428 & 0.0447214 \\
\hline
\end{tabular}

e) Determining the ideal solution matrix positive () and negative ideal solution () can be seen in the following table: $A^{+} A^{-}$

table 5

Ideal Solution Positive () $A^{+}$

\begin{tabular}{|c|c|c|c|c|c|c|}
\hline \multirow{4}{*}{$\begin{array}{c}\text { Ideal Solution } \\
\text { Positive }\end{array}$} & $\mathbf{V ~ ( i , ~ 1 ) ~}$ & $\mathbf{V ~ ( i , ~ 2 ) ~}$ & $\mathbf{V ~ ( i , ~ 3 ) ~}$ & $\mathbf{V ~ ( i , ~ 4 )}$ & $\mathbf{V ~ ( i , ~ 5 ) ~}$ & $\mathbf{V ~ ( i , ~ 6 ) ~}$ \\
\cline { 2 - 7 } & 0.1414214 & 0.0894428 & 0 & 0.0447214 & 0.0894428 & 0.0447214 \\
\cline { 2 - 7 } & 0.1414214 & 0.0894428 & 0 & 0.0447214 & 0.0894428 & 0.0447214 \\
\cline { 2 - 7 } & 0 & 0.0894428 & 0.11547 & 0.0447214 & 0.0894428 & 0.0447214 \\
\cline { 2 - 7 } & 0 & 0.0894428 & 0.11547 & 0.0447214 & 0.0894428 & 0.0447214 \\
\cline { 2 - 7 } & 0 & 0.0894428 & 0.11547 & 0.0447214 & 0.0894428 & 0.0447214 \\
\hline$A^{+}$(V Max) & 0.1414214 & 0.0894428 & 0.11547 & 0.0447214 & 0.0894428 & 0.0447214 \\
\hline
\end{tabular}

Table 6.

Ideal Solution Negative () $A^{-}$

\begin{tabular}{|c|c|c|c|c|c|c|}
\hline \multirow{4}{*}{$\begin{array}{c}\text { Ideal Solution } \\
\text { Negative }\end{array}$} & $\mathrm{V}(\mathrm{i}, 1)$ & $\mathrm{V}(\mathrm{i}, 2)$ & $\mathrm{V}(\mathrm{i}, 3)$ & $\mathrm{V}(\mathrm{i}, 4)$ & $\mathrm{V}(\mathrm{i}, 5)$ & $\mathrm{V}(\mathrm{i}, 6)$ \\
\cline { 2 - 7 } & 0.1414214 & 0.0894428 & 0 & 0.0447214 & 0.0894428 & 0.0447214 \\
\cline { 2 - 7 } & 0.1414214 & 0.0894428 & 0 & 0.0447214 & 0.0894428 & 0.0447214 \\
\cline { 2 - 7 } & 0 & 0.0894428 & 0.11547 & 0.0447214 & 0.0894428 & 0.0447214 \\
\cline { 2 - 7 } & 0 & 0.0894428 & 0.11547 & 0.0447214 & 0.0894428 & 0.0447214 \\
\cline { 2 - 7 } & 0 & 0.0894428 & 0.11547 & 0.0447214 & 0.0894428 & 0.0447214 \\
\hline$A^{-}$(V Min) & 0 & 0.0894428 & 0 & 0.0447214 & 0.0894428 & 0.0447214 \\
\hline
\end{tabular}

f) Counting appropriate or distance al ternatif of positive ideal solution () with the formula: $S^{+}$

$$
S_{i}^{+}={ }_{j=1}^{n} V_{i j}-V_{j}^{+2}
$$

Counting appropriate or distance al ternatif from the negative ideal solution (): $S^{-}$

$$
S_{i}^{-}={ }_{j=1}^{n} V_{i j}-V_{j}^{-2}
$$

The research result shows seperasi (distance) positive ideal solution and negative ideal solution distance as in the following table:

Table 7.

NilaiSeperasi (Distance)

\begin{tabular}{|l|c|c|c|c|c|c|c|c|}
\hline \multirow{5}{*}{} & $\mathrm{V}(\mathrm{i}, 1)$ & $\mathrm{V}(\mathrm{i}, 2)$ & $\mathrm{V}(\mathrm{i}, 3)$ & $\mathrm{V}(\mathrm{i}, 4)$ & $\mathrm{V}(\mathrm{i}, 5)$ & $\mathrm{V}(\mathrm{i}, 6)$ & $S^{+}$ & $S^{-}$ \\
\cline { 2 - 8 } & 0.1414214 & 0.0894428 & 0 & 0.0447214 & 0.0894428 & 0.0447214 & 0.11547 & 0.1414214 \\
\cline { 2 - 8 } & 0.1414214 & 0.0894428 & 0 & 0.0447214 & 0.0894428 & 0.0447214 & 0.11547 & 0.1414214 \\
\cline { 2 - 8 } & 0 & 0.0894428 & 0.11547 & 0.0447214 & 0.0894428 & 0.0447214 & 0.1414214 & 0.11547 \\
\cline { 2 - 8 } & 0 & 0.0894428 & 0.11547 & 0.0447214 & 0.0894428 & 0.0447214 & 0.1414214 & 0.11547 \\
\hline$A^{+}$(V Max $)$ & 0.1414214 & 0.0894428 & 0.11547 & 0.0447214 & 0.0894428 & 0.0447214 & & \\
\hline$A^{-}$(V Max $)$ & 0 & 0.0894428 & 0 & 0.0447214 & 0.0894428 & 0.0447214 & & \\
\hline
\end{tabular}

g) Calculating the relative proximity of each alternative to ideal psolusi positive $(\mathrm{ci}+)$ with the following formula:

with $\mathrm{i}=1,2,3, \ldots, \mathrm{m}$

$$
c_{j}^{+}=\frac{S_{i}^{-}}{S_{i}^{-}+S_{i}^{+}}
$$


Table 8.

Calculating Relative Closeness

\begin{tabular}{cccc}
\hline I & \multicolumn{1}{c}{$S^{+}$} & $S^{-}$ & \multicolumn{1}{c}{$C^{+}$} \\
\hline 1 & 0.11547 & 0.1414214 & 0.60000037233552 \\
2 & 0.11547 & 0.1414214 & 0.60000037233552 \\
3 & 0.1414214 & 0.11547 & 0.39999962766448 \\
4 & 0.1414214 & 0.11547 & 0.39999962766448 \\
5 & 0.1414214 & 0.11547 & 0.39999962766448 \\
\hline
\end{tabular}

h) Alternative rank

In the following table is the result of the calculation process that has been ordered from the largest value to the smallest value. The results of each beneficiary rangking house surgeon can be seen in the table below:

Table 9.

Results ranking process

\begin{tabular}{clccc} 
No. & Name & $S^{+}$ & $S^{-}$ & $C^{+}$ \\
\hline 1 & Mawan & 0.11547 & 0.1414214 & 0.60000037233552 \\
2 & Mursiah & 0.11547 & 0.1414214 & 0.60000037233552 \\
3 & Asri & 0.1414214 & 0.11547 & 0.39999962766448 \\
4 & Misiah & 0.1414214 & 0.11547 & 0.39999962766448 \\
5 & Wagiman & 0.1414214 & 0.11547 & 0.39999962766448 \\
\hline
\end{tabular}

Based on calculations by the application of TOPSIS method, results ranking process stated order from the highest value is Mursiah, Mawan, Asri, Misiah and Wagiman. To determine the value of the final beneficiaries house surgeon, then the value that has been in process with TOPSIS method can be adapted to the decision table.

Table 10.

Results Final Recommendations

\begin{tabular}{ccccc}
\hline No. & Name & Final score & variables & Predicate \\
\hline 1 & Mawan & 0.60000037233552 & A & Recommendation \\
2 & Mursiah & 0.60000037233552 & A & Recommendation \\
3 & Asri & 0.39999962766448 & B & TidakRekomendasi \\
4 & Misiah & 0.39999962766448 & B & TidakRekomendasi \\
5 & Wagiman & 0.39999962766448 & B & TidakRekomendasi \\
\hline
\end{tabular}

\section{Conclusion}

Based on research at the Department of Housing and Settlement Region Deli Serdang, the authors conclude that:

1. Implementation of Algorithms TOPSIS for Decision Support System Receiver surgical assistance to the Department of Housing and Area Settlement Deli Serdang running based on the description that has been described in the five previous chapters and programs that have been completed are designed and constructed in the form of Decision Support System Receiver surgical assistance to the Department of Housing and Area Deli Serdang settlements can run properly.

2. Software that digunakanyaitu Adobe Dreamweaver CS6, Xampp, MySqldan Mozilla Firefox successfully designed and can be used to select beneficiaries house surgeon at the Department of Housing and Settlement Region Deli Serdang in accordance with the identification of the problem. Department of Housing and Settlement Region easier to identify beneficiaries, house surgeon with precise and accurate. And in the courses that have been built are still many shortcomings that must be improved and developed so much better than before.

\section{Reference}

[1] Ahmad, A., C.(2016). Penerapan Metode Topsis Untuk Menentukan Prioritas Kondisi Rumah. Jurnal SIMETRIS.

[2] Eva, Y., Roki, Z.(2018). Sistem Pendukung Keputusan Seleksi Penerima Bedah Rumah Menggunakan Metode Simple Additive Weighting (SAW). Jurnal TEKNOIF.

[3] Kusrini,(2018). Konsep dan Aplikasi Sistem Pendukung Keputusan. Yogyakarta: Andi.

[4] Lukman, A., \&Munawir(2018). Sistem Informasi Manajemen. Banda Aceh: Lembaga Komunitas Informasi Teknologi Aceh (KITA).

[5] Muhammad, A., S., Andi, T., \&Masnawati(2017). Sistem Pendukung Keputusan Penentuan Penerima Program Bantuan Daerah Menggunakan Weight Product. Jurnal Seminar Ilmu Komputer dan Teknologi Informasi.

[6] Murni, M., \& Bosker, S.(2018) Sistem Pendukung Keputusan Penilaian Hasil Belajar Dengan Metode Topsis. Medan: CV. Rudang Mayang. 